\title{
Levitical Singers in Rabbinic Sources: Echoes of an Ancient Dispute
}

\author{
Hallel Baitner \\ University of Oxford, Oxford, United Kingdom \\ Hallel.baitner@orinst.ox.ac.uk
}

\begin{abstract}
The Hebrew Bible reflects ambiguity concerning the historical existence of the Levites as a group distinguished from the priesthood. Post-exilic and late Second Temple sources also present a variety of voices concerning the extent to which Levites participated in the temple's worship. This article argues that, while rabbinic sources appear to portray a straightforward retrospective description of the Levites as a group of templeservants who are clearly subordinated to the priests and responsible for temple singing, a closer reading reveals differences of opinion. Disagreements concerning the exact place in the temple in which the Levites used to sing, reflect significantly different views concerning the status of the Levites in the temple and the importance of their singing. This rabbinic dispute echoes similar late Second Temple period controversies, and sources from the two periods may shed light on each other.
\end{abstract}

\section{Keywords}

Levites - Bible - Josephus - Philo - Qumran - Early Rabbinic Literature - Temple 


\section{Introduction $^{1}$}

"The obscure history of the Levites" - thus Baruch A. Levine entitled the short survey that appears as an appendix to his commentary on Numbers $8 .^{2}$ Indeed, the origin of the Levites, their definition as a separate tribe, their relationship with the Aaronic priesthood, and their historical functions in the temple are unclear. The literary sources - from the earliest biblical texts to the late Second Temple and rabbinic depictions - give various and sometimes extremely different answers to these historical questions. This article focuses on rabbinic depictions of the Levites as temple singers and shows that these depictions are deeply related to the question of the historical Levites, especially in the late Second Temple period, and may even shed new light on it.

\section{The Levites in the Bible}

Let us begin with a short survey of some main aspects of the problem. ${ }^{3}$ The Pentateuch includes different and sometimes contradictory descriptions of the Levites. Deuteronomic sources and priestly sources offer conflicting accounts of the relationship between Levites and priests. The priestly sources, especially the book of Numbers, present a clear distinction between Levites and priests and describe the Levites as subordinate temple functionaries. Two roles of the Levites are delineated in Num 1:50-51; 3:5-10, and 18:2-3: They handle the tabernacle, meaning that they dismantle the structure, transport its parts, and rebuild it elsewhere. They also guard the tabernacle and its vessels from the unauthorized approach of Israelites. A third role, characterized as service (using the Hebrew root שרת), is not completely clear. It is described alternatively as the service of the tabernacle (Num 1:50), the service

1 I wish to thank Prof. Martin Goodman, Prof. Menahem Kahana, Prof. Hindy Najman, and Prof. Ishay Rosen-Zvi, who have commented on early versions of this article. The English translations of biblical passages in this article are from the NRSV, with my emendations. Translations of the Tosefta are based on Neusner, Tosefta. Other rabbinic sources, unless otherwise indicated, are from https://www.sefaria.org/, with my emendations. The translations of Philo and Josephus are based on the LCL editions.

2 Levine, Numbers, 279-9o.

3 A comprehensive discussion on the Levites in the Hebrew Bible can be found in Haran, Temples, 57-131. For updated surveys of both biblical and Second Temple sources, see Kugler, "Levi, Levites" and "Priests and Levites," as well as Janzen, Politics, 95-137. A detailed bibliography on the Levites in the Hebrew Bible and Second Temple period literature appears in Stackert, "Cultic Status," 199-20o n. 1-2. For a concise survey of sources and bibliography on the Levites in literature of the Second Temple period, see Fraade, "Shifting," 116 n. 23. 
of the congregation (Num 16:9) or the service of the priests (Num 18:2). Several verses emphasize that the Levites should not participate in sacrificial acts, for instance: "But they must not approach either the utensils of the sanctuary or the altar, otherwise both they and you will die" (Num 18:3).

The role of the Levites is described quite differently in Deuteronomy. The Deuteronomist does not differentiate at all between priests and Levites, and repeatedly refers to the priests as "the Levitical priests" (הכהנים הלוים)..4 Several Deuteronomic laws do mention Levites who live "in your towns" (בשעריך), but scholars have shown that these Levites are actually priests who live far from the central temple. The Deuteronomist recognizes the right of these Levites to go to "the place that the Lord will choose" and to serve there as priests, even including consumption of sacrifices. ${ }^{5}$

The book of Ezekiel contains echoes of the two approaches. Chapter 44 arguably attempts to bridge the gap between them, explaining that all of the Levites were originally considered priests, but some were demoted because they sinned and worshiped idols. They can no longer sacrifice on the altar, but only "be ministers in my sanctuary, having oversight at the gates of the temple, and serving in the temple; they shall slaughter the burnt offering and the sacrifice for the people, and they shall attend on them and serve them" (Ezek 44:11). Only one Levitical family, the sons of Zadok, remained loyal to the worship of God, and they were therefore the only ones to retain the right to serve as priests. ${ }^{6}$

Scholars have tried to reconstruct the historical processes that could have led to the disparities between the sources, and they have arrived at differing, and occasionally opposite, conclusions. ${ }^{7}$ For the purposes of this article, it

4 See, for example, Deut 17:9.

5 See Deut 18:6-8. Scholars have related the status of the Levites in Deuteronomy to the Deuteronomic idea of the centralization of cultic worship, claiming that the prohibition against local altars caused the local priests to lose their jobs, hence these priests are mentioned alongside poor people (see, for example, Deut 14:29). See, for instance, Emerton, "Priests and Levites." For a more recent account of this question, see Altman, "Levites in Your Gates." The Rabbis offered a different interpretation of Deut 18:6-8, claiming that these verses do not deal with an "actual Levite," but rather with Levites who are eligible to serve, namely: priests. See Sifre on Deuteronomy 168 (Finkelstein, Sifre, 216).

6 The bibliography on the issue of priests and Levites in Ezekiel is massive, and a full treatment of the topic is outside the scope of this article. Julius Wellhausen and some of his successors posited that Ezek 44 expresses a transitional stage from the reality described in Deuteronomy, in which all Levites are priests, to that of Numbers, in which the Levites have a secondary status. Later studies, however, have argued that Ezekiel features a later revision of the priestly laws, and I follow this approach in presenting the work as a response to $\mathrm{P}$ as well as D. For updated discussion and bibliography, see MacDonald, Priestly Rule, esp. 38-47.

7 The various suggestions are described by Haran, Temples, 71-83. 
suffices to observe that, in the early biblical material, the status of the Levites varies between that of complete identity with the priesthood and that of a secondary group related to but clearly distinct from the priests.

Early Second Temple sources introduce two distinct roles for the Levites in the temple-singers (משוררים) and gatekeepers (שוערים). Here as well, different sources tell different stories. The approach of Chronicles is the clearest. The Chronicler narrates that David was the first to appoint some of the Levites as singers, which he did while bringing the ark of the covenant to Jerusalem: "David also commanded the chiefs of the Levites to appoint their kindred as the singers to play on musical instruments, on harps and lyres and cymbals, to raise loud sounds of joy" (1 Chr 15:16). After the ark was placed in Jerusalem, as part of his preparations for the construction of the temple, David arranged the Levites in sections and gave a specific role to each section: "Twenty-four thousand of these shall have charge of the work in the house of the Lord, six thousand shall be officers and judges, four thousand gatekeepers, and four thousand shall offer praises to the Lord with the instruments that I have made for praise" (1 Chr 23:4-5). The Levites assumed their duties when Solomon built the temple (2 Chr 5:12). These events do not appear in the parallel descriptions in the books of 2 Samuel and 1 Kings, which do not mention a class of liturgical singers. ${ }^{8}$ It is likely that the Chronicler derived these elements from temple worship current in his own times, either from actual practices or from idealized notions of desirable practices. ${ }^{9}$

8 Unlike sources from the Second Temple period, which abound in descriptions of liturgical singing in the temple, sources from the First Temple period barely mention such singing. An exception, perhaps the only exception, concerns the temple of Beit El: "Take away from me the noise of your songs; I will not listen to the melody of your harps" (Amos 5:21-23). Some earlier biblical scholars concluded that liturgical singing was established in post-exilic times. This view became less common during the twentieth century, as scholars pointed out the relationship between certain chapters in Psalms and liturgical texts from the ancient Near East. They also noted that, in his annals, the Assyrian king Sennacherib mentions "male and female singers" whom he received from Hezekiah. Such evidence suggests that liturgical singing already existed towards the end of the First Temple period. See Hurvitz, "Lishkhot Sharim"; Sarna, "Psalms."

9 Despite the quantity and variety of temple duties that the Chronicler ascribes to the Levites, quite a few verses emphasize the unique duties of the Aaronic priesthood and describe the Levites as secondary temple servants. Scholars have tried to explain this tension through historical reconstructions of the book's development. Some of them claimed that the book 
In contrast to the straightforward description of Chronicles, the books of Ezra and Nehemiah present a more complicated picture. In some occurrences, the singers and the gatekeepers are described as Levites, similarly to Chronicles (e.g., Neh 12:24-25). However, in other occurrences, the gatekeepers and the singers, as groups, are listed besides the Levites, which gives the impression that those groups are distinct from the Levites, or, at least, not completely included among them (e.g., Ezra 7:24). This variation, as well as the uneven attitude towards the status of the Levites reflected in Ezra and Nehemiah, were related by scholars to the complicated authorship of these books. Once again, different and sometimes opposing suggestions have been raised..$^{10}$ Despite the controversy, it seems that most scholars would agree that in Ezra and Nehemiah, like in Chronicles, Levites and priests are described as distinct groups. ${ }^{11}$

Some later sources diverge from this view and revert to the Deuteronomistic model of Levites and priests as one group. The earliest preserved Second Temple source that features this approach is the prophecy of Malachi (2:1-9),

originally presented a view similar to that of Deuteronomy, where priests and Levites are equal, and statements about the secondary status of the Levites belong to later additions. Other scholars, however, presented the reverse trajectory, claiming that the sections concerning the various temple duties of the Levites are later additions to a text that originally posited the distinctiveness of the priestly class. See Knoppers, "Levites in Chronicles"; Japhet, Ideology of Chronicles, 174-81.

10 Min, Levitical Authorship, 72-86, 116-40. Min primarily argues against H.G.M. Williamson's claim for priestly authorship of the later layers of the books.

11 The different descriptions of the Levites in the post-exilic books bear implications for a different question-the involvement of Levites in the compilation of Psalms. Susan Gillingham recently argued that a class of Levitical singers were involved in the compilation of Psalms. See Gillingham, "Levitical Singers." Her claim is based, inter alia, on a certain reading of the depictions of the Levitical singers in Chronicles and Ezra and Nehemiah, which does not fully consider the differences between the sources. While the word "Levi" appears in Psalms only once (Ps 135:20: the "house of Levi," besides the "house of Aaron" and the "house of Israel"), certain collections of psalms are attributed to the sons of Korah (Pss 42, 44-49, 84, 85, 87, 88) and to Asaph (Pss 50, 73-83), without any additional information on their lineage. Such information does appear in Chronicles and in Ezra and Nehemiah, but with discrepancies. The Asaphites, the sons of Asaph, are explicitly described as Levitical singers in Chronicles, while in Ezra and Nehemiah they are described both as Levitical singers (Ezra 3:10; Neh 12:46) and as a group of singers distinct from the Levites (Ezra 2:41; Neh 7:44). The sons of Korah are portrayed as a Levitical group only in Chronicles, usually as gatekeepers (1 Chr 9:19; 26:1, 19) and once as singers (2 Chr 20:19). These conflicting descriptions problematize the conclusions of Gillingham, which depend, to my mind, on a harmonizing reading of the sources. 
who blames the priests for corrupting the covenant of Levi by their sins. ${ }^{12}$ In the Aramaic Levi Document, which is mostly dated to the third century в $\mathrm{CE},{ }^{13}$ Levi the son of Jacob is described as a priest who teaches the priestly and sacrificial laws to his sons. Similar views can be found in Jubilees and in the Testament of Levi, both of which describe how Levi, the son of Jacob, was sanctified and became a priest. According to these sources, all descendants of Levi are considered priests. ${ }^{14}$ There is further evidence for the existence of this view in the

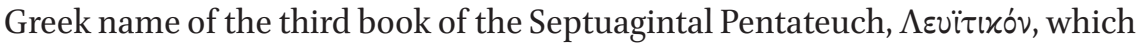
is first mentioned by Philo. ${ }^{15}$ Since the Levites appear only twice in Leviticus, and never in the context of the tabernacle worship, the Greek name can only make sense under the assumption that Levites are priests. The rabbinic name of the book, תורת כהנים ("the law of the priests") offers a clear contrast.16

There is no reference to the Levites as a group in the book of Sirach. It does mention a singing after the high priest offers a sacrifice (Sir $5^{\circ}: 18$ ), but the identity of the singers is not stated.

Levites and priests are again described as distinct groups in Qumranic literature. They appear as such in the Temple Scroll, the Damascus Document, and the War Scroll. The Temple Scroll ascribes temple duties to the Levites, including the right to slaughter sacrifices (22:4, compare Ezek 44:11). The Temple Scroll is unique in claiming that the Levites are also entitled to a receive certain part- "the shoulder that remains from the leg"-from the shelamim, the peace offerings. ${ }^{17}$ However, although the notion that singing accompanies sacrifices is well attested in Qumranic liturgical texts, we do not find any connection between Levites and singing in this corpus. ${ }^{18}$

See O'Brien, Priest and Levite. See also Baruch Schwartz's review of this book (Schwartz, "O'Brien").

13 On the dating of the Aramaic Levi Document, see Kugler, Patriarch to Priest, 131-35.

14 For a description of this tradition and its exegetical background, see Kugel, "Levi's Elevation." Kugel argued that this tradition was based on an interpretation of Jacob's vow after his dream in Beit-El. Since Jacob promised God: "of all that you give me I will surely give one-tenth to you," he needed to find a priest or a Levite to whom he could give the tithe. According to this tradition, his son Levi was chosen for this role.

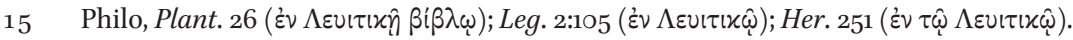

16 Levine, "Leviticus, Book of"; Harlé and Parlon, Lévitique, 14.

17 On this perquisite and its possible exegetical background, see Milgrom, "Temple Scroll"; Stackert, "Cultic Status."

18 In 4Q264a $12-4$, according to the reading of Noam and Qimron, there is a law that refers to priests (!) and musical instruments (כלי שיר). See Noam and Qimron, "Sabbath Laws," esp. 72-80. At this point I do not agree with Richard Hidary's critique of the reading of Noam and Qimron, saying that the Levites and not the priests used to sing in the temple, because there is no evidence for such a view in the Qumranic literature. See Hidary, "Revisiting," esp. 71-72. Menahem Kahana has suggested that the Qumranic phrase כהני קורב (the 
One small Qumranic fragment $\left(4 \mathrm{Q}_{423} 5\right)$, despite the uncertainty of its reading, may indicate tension between Levites and priests. ${ }^{19}$ Elisha Qimron ${ }^{20}$ reads the fragment, which belongs to the text known as $4 \mathrm{QInstruction}$, as follows:

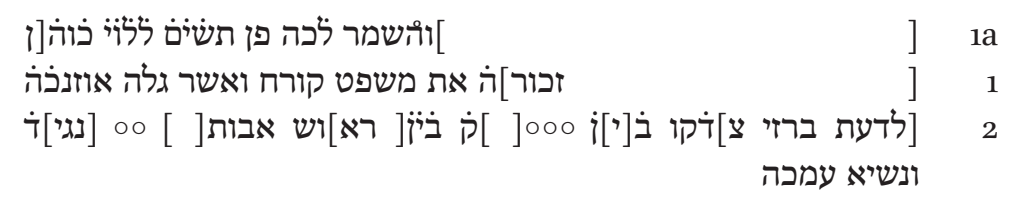

The reading of the words משפט קורח (the judgment of Korah) is certain and affirmed by a fragment of another copy of the text (4Q418a 3). Korah was a Levite who demanded participation in the temple service and equality with priests, while challenging the leadership of Moses and Aaron. The text probably mentions Korah's "judgment" as a warning against a certain behavior. However, the description of that behavior was not fully preserved. Line $1 \mathrm{a}$ may shed light on it, but its reading is problematic. This line was added on the blank upper margin of the column by two different scribes and it is very difficult to read. Torleif Elgvin, who was the first to publish the text (DJD 34), followed the suggestion of M.G. Abegg in reading the line as והשמר לכה פן תשיב (D) להוי (תשוב) ללוי כהן/), and he translated: "and take care lest you give back to Levi the Priest." He understood these lines as a warning against ungodly leaders. ${ }^{21}$ In a special monograph that aims to reexamine the readings of the fragments of 4 QInstruction, Eibert Tigchelaar commented on Elgvin's reading: "The last three words are barely legible, and I am not able to affirm the editor's reading." ${ }^{22}$ Qimron, who reads פן תשי/וב instead translates the line as "do not appoint a Levite to be a priest." The text, according to Qimron's reading, warns

priests of qoreb), found in the Songs of the Sabbath Sacrifice, should be translated as "the priests of song" based on the rabbinic meaning of the root. Noam Mizrahi rejected Kahana's opinion and suggested another meaning for the phrase. See Mizrahi, "Priests of Qoreb." Kahana repeated his suggestion while responding to Mizrahi in: Kahana, Sifre, 4:869-70. Beckwith, "Courses of Levites," has tried to relate the number of psalms mentioned in "The David Composition" in the Qumranic Psalms Scroll to an assumed cycle of twenty-four courses of Levitical singers (following Chronicles). This claim seems very unlikely, however, for several reasons. See Wacholder, "David's Eschatological Psalter," 35 n. 5 .

19 I wish to thank Prof. Menahem Kister for bringing this fragment and its readings to my attention.

20 Qimron, Ha-hiburim Ha-'Triyim, 2:182.

21 Strugnell et al., Mûsār Lĕ Mèvîn, 505-33.

22 Tigchelaar, 4QInstruction, 143. 
against Levites who wish to become priests, and the mention of Korah may be better understood in this context. ${ }^{23}$ If Qimron is correct, then it is possible that the author of this text, who probably lived in the second century вСE, may have been bothered by possible extension of the Levitical duties in his days.

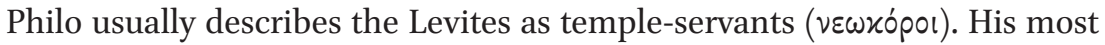
detailed account appears in Spec. 1:156:

After bestowing these great sources of revenue on the priests, he did not ignore those of the second rank either, namely the temple attendants. Some of these are stationed at the doors as gatekeepers at the very entrances, some within in front of the sanctuary ( $\varepsilon l \sigma \omega \kappa \alpha \tau \dot{\alpha} \tau \dot{o} \pi \rho o ́ v \alpha o v)$ to prevent any unlawful person from setting foot thereon, either intentionally or unintentionally. Some patrol around it turn by turn in relays by appointment night and day, keeping watch and guard at both seasons. Others sweep the porticoes and the open court, convey away the refuse and ensure cleanliness. All these have the tithes appointed as their wages, this being the portion settled on them as temple attendants.

In this paragraph, Philo describes in detail the Levites' roles as gatekeepers, guards and cleaning workers. However, in none of his extant writings does Philo ever mention liturgical singing in the temple or mention the Levites in that context. ${ }^{24}$

23 James M. Scott has suggested a different interpretation of the term "the judgment of Korah." He claimed that this section of 4QInstruction warns against undermining the authority of the leaders, and that the reference to Korah hints at a certain event in the development of the Yahad, when some members rejected the authority of the Teacher of Righteousness. Although his paper deals mainly with $4 \mathrm{Q}_{423}$, Scott does not refer to the additional line in the upper part of the fragment. See Scott, "Korah and Qumran."

24 For other descriptions of Levites as temple servants in Philo's writings, see Mos. 1:316; 2:174; Fug. 93; Praem. 74. In the last-mentioned text, Philo describes Korah and his supporters as "temple attendants, servitors of the sanctuary, appointed to the office of gate-keepers

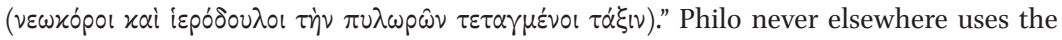

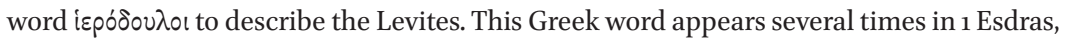
both as an appellation for the Levites (1 Esd 1:3) and as a term that probably parallels the Hebrew word נתינים (compare 1 Esd 5:29 and Ezra 2:43). Adolf Büchler claimed that the

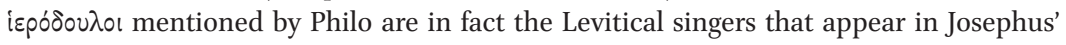
writings (see below). See Büchler, Priester, 123-25. The claim is, however, unconvincing, and there is no point to glossing over the fact that Philo does not mention Levitical singers. 
Josephus' description of the Levites is complex. ${ }^{25} \mathrm{He}$ has integrated many details from Chronicles into his account of the events described in the books of Samuel and Kings. Levitical singers thus show up in his account of David's preparations for the building of the temple, as well as in the ceremonies surrounding its establishment in the days of Solomon. ${ }^{26}$ Again following Chronicles, Josephus also mentions Levites as singers in his account of the war of Jehoshaphat against Amon and Moab, ${ }^{27}$ and similarly in his description of the Passover celebrated by Hezekiah. ${ }^{28} \mathrm{He}$ also describes, following the book of Ezra, the role of the Levites in the inauguration of the altar after the return from exile. ${ }^{29}$ However, towards the end of the eleventh book of The Jewish Antiquities and onwards, as soon as Josephus turns to describe post-biblical events, he barely mentions the Levites (the two only exceptions will be discussed below), even though he continues to mention the priests frequently. The Levites crop up in Josephus' description of Onias' temple in Egypt, where priests and Levites are said to have been appointed, but without any further details. ${ }^{30}$ The second reference, which appears near the end of the work, is more significant, because it includes a description of Levitical singers. ${ }^{31}$ Josephus tells of an event that took place during the procuratorship of Albinus $(62-64 \mathrm{CE})$ :

Those of the Levites - this is one of our tribes - who were singers of hymns ( $\dot{\mu} \mu \omega \delta \delta i$ ) urged the king to convene the Sanhedrin and get them permission to wear linen robes ( $\lambda เ v \hat{\eta} \nu \sigma \tau 0 \lambda \eta \dot{\eta} \nu)$ on equal terms with the priests, maintaining that it was fitting that he should introduce, to mark his reign, some innovation by which he would be remembered. Nor did they fail to obtain their request; for the king, with the consent of those who attended the Sanhedrin, allowed the singers of hymns to discard their former robes and to wear linen ones such as they wished. A part

25 For a full survey on the Levites in the writings of Josephus, see Begg, "Levites in Josephus."

26 A.J. 7.305; 8.94, 176. Compare 1 Chr 25:1; 2 Chr 5:12-13.

27 A.J. 9.11-12. Cf. 2 Chr 20.

28 A.J. 9.269. Cf. 2 Chr 29:27.

29 A.J. 11.70, 8o. Cf. Ezra 3:10-11.

$30 \quad$ A.J. $13.63,73$.

31 Temple singers in Jerusalem of the Hellenistic and Roman periods are mentioned in two other places in Josephus' writings. However, they are mentioned very briefly, and nothing is said about their lineage. In A.J. 12.142, Josephus quotes a letter of Antiochus III, in

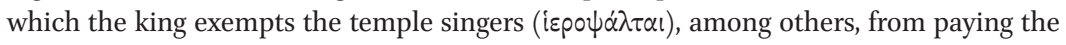
poll tax. In B.J. 2.321, he describes how "every priest and every servant of God ... and also the cithara-players and the [choral] singers (i $\mu v \omega \delta 0^{\prime}$ ) with their instruments" went out of the temple to persuade the people to prevent the war with the Romans. 


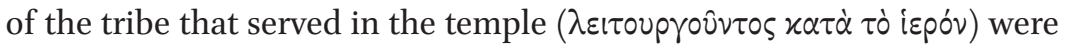

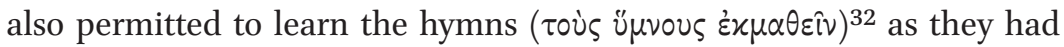
requested. All this was contrary to the ancestral laws, and such transgression was bound to make us liable to punishment.

JOSEPHUS, A.J. 20.216-218.

This short episode raises some difficulties. The main problem is that we do not know what the precise roles of the Levites were before they made their request. As I said earlier, this ambiguity is also caused by the fact that Josephus does not write anything on the Levitical roles in the last nine books of The Jewish Antiquities. It is clear, though, that the Levites' request aroused Josephus' strong objection, as he describes it as a transgression against the laws of the fathers which was one of the reasons for the destruction. We may assume that the objection of Josephus, as a priest, probably reflects the priestly approach towards the Levites' attempt of elevating their status in the temple. Therefore, it may point to a tension between Levites and priests in the years before the Jewish Revolt. ${ }^{33}$

Pointing out this tension would be sufficient for my later discussion on the rabbinic sources, but I still want to suggest a reconstruction of the realia behind this difficult account of Josephus. It seems that there were (at least) two groups of Levites in the temple: a group of singers and a group whose members performed some kind of $\lambda \varepsilon i \tau o u p \gamma i \alpha .{ }^{34}$ The end of the passage indicates that the request of the Levites was twofold. They asked for priestly robes for the Levitical singers, as well as permission for the other Levitical group to learn the hymns. The reason for the second request is not clear-what did the Levites hope to achieve by increasing the number of Levites who know the hymns? It seems to me that this request will make more sense if we assume that the group of the singers was made up of both Levites and non-Levites. Thus, the request can be read as an attempt by the Levitical singers to increase their power within the group, by allowing Levites (and only Levites) who were not members of the group to learn the hymns. Such a move would have given priority to Levites who wanted to be singers, and would consequently increase the relative portion of Levites in the group. It also might have strengthened the affinity between the Levites and the temple singing.

32 Louis Feldman, in the LCL edition, translates: "to learn the hymns by heart." However, this meaning of the Greek verb '̇ $x \mu \alpha \nu \theta \dot{\alpha} v \omega$ is not found elsewhere in Josephus' writings.

33 Feldman, Josephus's Interpretation, 61-62.

34 Meyer, "Levitische Emanzipationsbestrebungen," 727 
Josephus treats the Levites' requests as a terrible act contrary to the ancestral laws, a transgression that merited punishment. However, Chronicles twice mentions Levitical singers wearing linen vestments, most explicitly in the description of the establishment of Solomon's temple in 2 Chr 5:12: "All the Levitical singers, ... arrayed in fine linen (בוץ), with cymbals, harps, and lyres, stood east of the altar."35 Josephus himself, while describing the preparations for the building of the First Temple in A.J. 8.94, follows Chronicles and mentionslinen robes (made of $\beta v \sigma \sigma o ́ s)$ for both the Levitical singers and the priests. ${ }^{36}$ Did the verses of Chronicles serve as a precedent for the Levites' request from Agrippa II? Did those Levites try to recover the status of the Levites in accordance with the depictions of Chronicles, i.e., exclusively Levitical singing and entitlement to wearing priestly robes? Though Josephus does not explain the Levites' reasoning, it seems to me that the answer to these two questions is positive.

Finally, an unexpected reference to the Levitical singers appears in Plutarch's description of the temple during the Feast of Tabernacles (Sukkot), which is the only mention of Levites outside of Jewish and Christian literature in this period. ${ }^{37}$ Scholars have compared Plutarch's description to a passage in Tacitus that mentions priests (and not Levites) who sing in the temple to the accompaniment of musical instruments. ${ }^{38}$

This brief survey of Second Temple sources has aimed to provide some sense of the variety of voices concerning the Levites and their role in the temple. Scholars have tried, in different ways, to make sense of these different voices by suggesting historical developments during the period that might motivate the differences. These scholars have primarily focused on the gap between the Qumranic sources, which describe the Levites as a distinct group with certain duties, and pre-Qumranic sources such as Jubilees and the Aramaic Levi Document, which make no distinction between Levites and priests.

35 See also $1 \mathrm{Chr}$ 15:27. The Hebrew word bus is the post-exilic equivalent for the classical biblical word šeš, which describes the sort of textile that was used, according to Exod 28,

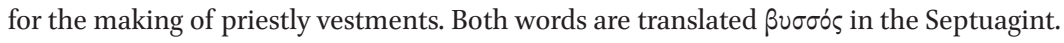
See Hurvitz, Lexicon, $48-51$.

36 Büchler (Priester, 137) sees this case as an example of the "thoughtless" (gedankenlos) way in which Josephus has treated his sources, since Josephus apparently failed to notice that the Levitical use of priestly vestments, which he describes here as a sin, is a practice that he himself has attributed to David.

Plutarch, Quaest. conv. 4.6.2 (= Mor. 671D-672B). See Stern, Greek and Latin Authors, 1:557-62.

38 Tacitus, Hist. 5.5. See Stern, Greek and Latin Authors, 1:43. For a recent discussion of these two sources, as well as references to earlier ones, see Dueck, "Feast of Tabernacles." 
George Brooke has claimed that towards the end of the first century BCE some Levites achieved leadership positions in the Yahad congregation and, under their influence, new texts were composed that granted higher status to the Levites. ${ }^{39}$ Robert Kugler argued that the lack of distinction between priests and Levites in certain pre-Qumranic texts reflects a critique against the priestly institutions in Jerusalem, similar to the accusations of Malachi against the priests. This critique, claimed Kugler, underlies the creation of the tradition about the elevation of Levi, the son of Jacob, to priesthood, and the description of all of his offspring as the carriers of the real priestly essence. However, the priestly Qumranic authors, according to Kugler, view themselves as entirely distinct from the priests in Jerusalem and hope to replace those errant priests in due time. The image of the Levites reflected in their works is, therefore, similar to the actual situation in Jerusalem during this period. ${ }^{40}$

Cana Werman has suggested the most radical solution to this problem, claiming that there never was a separate Levitical class during the Second Temple period. The differences between the sources reflect different ways to deal with this absence. Some did so by assimilating the Levites into the priesthood, hence the sources that describe all of the offspring of Levi as priests. The Qumranic authors also responded to the absence of the Levites, but rather than explaining it, they wished to fix it by reconstructing the biblical priestly order with a class of Levites distinct from the priests. Werman also claimed that the Levitical singers who, according to Josephus, asked for permission to wear priestly vestments, were actually descendants of Levites from the time of Ezra, who had assimilated into the families of the singers and the gatekeepers that did not originally belong to the tribe of Levi. ${ }^{41}$

I wish to reexamine these suggestions, offering evidence from rabbinic literature to shed new light on this issue.

\section{The Levites in Early Rabbinic Texts}

Rabbinic literature presents the Levites as a distinct class positioned between the priests and the Israelites, without questioning the existence of this class. ${ }^{42}$ Some sages, albeit not many, were considered to be Levites, ${ }^{43}$ a strikingly

39 Brooke, "Levi and Levites."

$40 \quad$ Kugler, "Priests of Qumran."

$41 \quad$ Werman, "Levi and Levites."

42 E.g., m. Giț. 5:8; m. Hor. 3:8.

43 R. Yehoshua ben Hanania, a prominent tannaitic sage, is presented as a Levite and reported to have served in the temple in his youth. See m. Macaś. Š. 5:9, which describes 
unique claim when one considers earlier literary sources: in the four hundred years between the beginning of the Hellenistic period and the destruction of the Second Temple we know the name of only one Levite, that of Joseph Barnabas from Cyprus (Acts 4:36). ${ }^{44}$ The epigraphical material attests to the same tendency. While the epigraphical material that predates $70 \mathrm{CE}$ does not contain even a single mention of Levites, three different people are described as "the Levite" in Hebrew and Aramaic inscriptions from late antique Palestinian synagogues. ${ }^{45}$ The shift in literary and epigraphical sources may reflect a strengthening of Levitical identity among Palestinian Jews in the first centuries after the destruction of the temple.

While most of the references to Levites in early rabbinic sources are related to the laws of tithes or to marital laws in the context of genealogical classes, quite a few sources deal with the Levitical duties in the temple. ${ }^{46}$ These sources assign two main duties to the Levites-singing and guarding. ${ }^{47}$ The most

R. Yehoshua receiving the tithe as a Levite, and t. Sukk. 4:5 for his testimony regarding the temple. R. Yohanan ben Gudgeda is also portrayed as a Levite who served in the temple (see below, n. 47), and R. Eliezer ben Yaakov relates that his uncle was a Levite who served as a guard in the temple (m. Midd. 1:2). In the amoraic period, although the personal name "Levi" was quite common among the rabbis, R. Yehoshua ben Levi (third-century Palestine) is the only rabbi explicitly identified as a Levite. See y. Ma'aś. Š. 5:5 (56b); y. Ber. 5:4 (9d) [= y. Giț. 5:9 (47b)]; b. Hul. 106b. See also Rosenthal, "Inscription," 365 n. 128.

44 Stern, "Aspects," 599-6oo. Stern assumed that Jews with the name Levi were Levites, but this is questionable. See Ilan, Lexicon, 2:431-32.

45 The Galilean stonecutter Yosef ben Levi Halevi (the Levite) signed his name in the synagogues of Bar'am and Alma, one of the donors of the synagogue in Hammat Gader is called Rav Tanḥum Halevi ben [H] alfa, and the name Yudan Halevi ben Simon appears in the synagogue of Susya in Hebrew as well as in Aramaic (Yudan Livaya (the Levite) ben Simon). See Naveh, 'Al Pesefas va-Even, 19, 22, 57, 120, 121.

46 A unique characteristic of rabbinic terminology is worthy of comment in this context. Alongside the common attribution "Levi" (in Hebrew: levi), the term "a son of Levi" (in Hebrew: ben (evi) also appears frequently. This unique term is also found, albeit less frequently, in the plural form: "sons of Levi" (bnei levi) besides "Levites" (leviyim). Although the plural bnei levi is a common biblical term, the singular ben levi does not appear in the Bible or in Second Temple literature. I was not able to find a pattern that would explain the distribution of the two terms in rabbinic literature, but I suggest a partial explanation that requires further research. The term ben levi mainly appears in contexts that do not feature any mention of another class, whether priestly or Israelite. See, for example, m. Ter. 4:2: "and he gave a seah to a Levite (לבן לוי) and a seah to a poor person." Contrast m. Pe'ah 1:6: "A priest or Levite (כהן או לוי) who purchase [grain of] a threshing floor, the tithes are theirs."

47 A few sources also assign the duty of closing gates to the Levites. According to Sifre to Numbers 63 (Kahana, Sifre, 1:156), even Levites older than fifty would lock the gates. See Kahana's commentary on this text in Kahana, Sifre, 3:426-28. In a story that appears in Sifre to Numbers 116 (Kahana, Sifre, 1b:336), R. Yoḥanan ben Gudgeda is described as one 
thorough description of the Levites as temple guards appears in the beginning of tractate Middot of the Mishnah. Unlike the parallel beginning of tractate Tamid, which refers only to priests, m. Mid. 1:1 also mentions Levites:

In three places the priests keep watch in the Temple: in the chamber of Avtinas, in the chamber of the spark, and in the fire chamber. And the Levites in twenty-one places: Five at the five gates of the Temple Mount; Four at its four corners on the inside; Five at five of the gates of the courtyard; Four at its four corners on the outside; One at the offering chamber; One at the chamber of the curtain, And one behind the place of the kapporet.

Later in the same chapter, in the context of a detailed description regarding the procedure for locking the fire chamber's gate, the mishnah reads:

There was a place there [in the fire chamber] one-cubit square on which was a slab of marble. In this was fixed a ring and a chain on which the keys were hung. When closing time came, the priest would raise the slab by the ring and take the keys from the chain. Then the priest would lock up within while the Levite was sleeping outside.

M. MID. 1:9

This depiction of a priest who locks the gate from inside while the Levite is outside is echoed in a homily of Sifre to Numbers:

And you and your sons with you are in front of the tent of the covenant (Num 18:3) - the priests from within and the Levites from outsides. You say: "the priests from within and the Levites from outside," or perhaps they are all from within? Scripture says: They are attached to you in order to perform the duties of the tent of meeting (Num 18:4), so what can

of the gatekeepers (שוערים) while R. Yehushua ben Hanania is described as one of the singers (משוררים). The parallel story in b. 'Arak. 11b depicts R. Yehoshua as wanting to help R. Yohanan in "closing the doors" (הגפת דלתות). The tosefta (t. Šeqal. 2:14) ascribes to R. Yoḥanan ben Gudgeda the role of overseeing "locking the gates" (נעילת שערים), contrary to the parallel mishnah (m. Šeqal. 5:1), where his name appears as Ben Gibber (according to the vocalization of MS Kaufmann A 5 ). However, other early rabbinic sources assign the role of closing the gates to the priests. See m. Mid. 1:9; Sifre Zuta to Numbers 18:8 (Horovitz, Sifre Zuta, 293); b. Yoma 18a; b. Sukkah 56 b. 
I learn from "And you and your sons with you are in front of the tent of the covenant"? The priests from within and the Levites from outside. ${ }^{48}$ SIFRE to Numbers 116

As Menahem Kahana noted, the midrash takes the phrase "in front of the tent of the covenant" to mean that the priests should watch from within the courtyard, which is located before the tent. Since the Levites are described as "attached to the priests," it is deduced that they should watch from outside of the courtyard. ${ }^{49}$ It is important to note that the Sifre considers the possibility that both Levites and priests should watch from within, but rejects it. ${ }^{50}$

Both the Sifre and Mishnah Middot describe the Levites as watchers located outside of the 'azara (temple courtyard). A similar picture arises from several sources that map a correspondence between the configuration of the Israelites' camp in the wilderness, as described in the Bible, and locations in Jerusalem and the temple. According to these sources, the "camp of the Levites," which surrounded the tabernacle in the wilderness, corresponds to the area between the Temple Mount and the gate of Nicanor, which is the gate of the 'azara. ${ }^{51}$

48 Kahana, Sifre, $1 \mathrm{~b}: 335$.

49 Kahana, 4:871.

50 Sifre Zuta to Numbers 18:3 (Horovitz, Sifre Zuta, 291) reads: "They shall perform duties for you and for the whole tent' (ושמרו משמרתך ומשמרת כל האהל)-It teaches that the priests and the Levites watch in twenty-four places in the temple. The priests [watch] in three [places], and the Levites [watch] in twenty-one." This version, which was adopted by Haim Saul Horowitz in his edition, is based on the attestation of Midrash Hagadol. In this version, the midrash only juxtaposes the mishnaic law of m. Mid. 1:1 to the verse. However, a different version of this derasha preserved in a quotation in Yalkut Shimoni reads as follows: "it teaches that the priests eat in the place of the Levites (חוכלים במקום) הלוים), and in twenty-four places they watch in the temple. The priest [watch] in three [places], and the Levites [watch] in twenty-one." Horovitz understood the peculiar phrase "the priests eat in the place of the Levites" as related to the consumption of sacrifices. Since the priests were only permitted to eat their special sacrifices inside the temple courtyard, which is not "the place of the Levites," this phrase makes no sense. For that reason, Horovitz rejected the version of Yalkut Shimoni. I suggest that the verb אכל should not be understood here in its usual sense (to eat, consume). A metaphorical usage of the term appears in t. 'Ohal. 13:9: "There is no such thing as twenty-five [handbreadths] from which the ground does not consume a handbreadth (אוכלת טפח)." The verb אכל means "diminish" in this text, and the Sifre Zuta as preserved in the Yalkut Shimoni might reflect a similar usage: "the priests eat (i.e., diminish) the place of the Levites." In other words, the priests also watch in places that were originally under the watch of the Levites.

51 See t. Kelim B. Qam. 1:12: "And just as in the wilderness there were three camps, the camp of the indwelling Presence of God (šekina), the camp of the Levites, and the camp of the Israelites, thus there were [three camps] in Jerusalem. From the gate of Jerusalem to the 
As Adolf Büchler has already shown, ${ }^{52}$ the tannaitic sources that deal with the watching place of the Levites in the temple tend to exclude the Levites from the temple courtyard. This tendency contrasts with Philo's explicit statement that the Levites also watch "inside, in front of the sanctuary." Büchler claimed that a similar tendency is present and similarly uniform in rabbinic discussions concerning the location of the Levitical singing in the temple. However, in the following section, I will point out other voices among rabbinic sources with regard to the singing.

Numerous rabbinic sources address the singing of the Levites. Some tannaitic homilies even attempt to find a biblical basis for such singing. ${ }^{53} \mathrm{In} \mathrm{m}$. Tamid 7:3, Levitical singing is included in the daily morning sacrifice known as the tamid:

They handed him the wine for libation. The deputy high priest stood at the horn of the altar with the flags in his hand, and two priests at the table of the fats with two trumpets in their hands. They blew a teki'ah, a teru'ah and a teki'ah. They then went and stood by Ben Arza, one [priest standing] on his right hand and one on his left. When he bent down to perform the libation, the deputy high priest waved the flags (הניף הסגן בסודרין) and Ben Arza struck the cymbals and the Levites sang the psalm. When they came to a pause, they blew a teki'ah, and the public bowed down. At every pause there was a teki'ah, and at every teki'ah, a bowing down.

Ben Arza, who is also mentioned elsewhere in the Mishnah as the "officer in charge of the cymbal, ${ }^{54}$ is said to signal the beginning of the singing immediately after the deputy high priest waves flags to signal that the wine has been poured on the altar. During the pause between the psalms, the priests blow the trumpets and the people bow. The following mishnah lists the daily psalms sung by the Levites. In m. Roš Haš. 4:4, the Mishnah relates an incident in which the witnesses who could testify to the appearance of the new moon did not arrive on time, and consequently, the Levites went wrong or disgraced

gate of the Temple Mount is the camp of Israel. From the gate of the Temple Mount to the gate of Nicanor is the camp of the Levites. From the gate of Nicanor and inward is the camp of the šekina." See also Sifre to Numbers 1 (Kahana, Sifre, 1:8).

52 Büchler, Priester, $13^{2-36 .}$

53 Noam and Qimron, "Sabbath Laws," 77-78; Kahana, Sifre, 4:871-73.

$54 \quad$ m. Šeqal. 5:1. See also t. Šeqal. 2:14. 
themselves (נתקלקלו) in their singing. Although the details of this event are unclear, the singing evidently went wrong because of confusion concerning the additional sacrifice that must be brought at the start of the new month. The Tosefta (t. Pesah. 4:11) narrates that the Levites used to sing the Hallel (Pss 113-118) as they stood on the dukan, the platform, while the people sacrificed their Passover sacrifices: "the Levites stand on their platform (דוכנן) and complete the Hallel." These descriptions suggest a close connection between the singing of the Levites and sacrificial actions, and they indicate that the singing should occur at the same time as the offering of the sacrifice or immediately after it. ${ }^{55}$ By depicting a close relationship between the Levites and the sacrificial worship, these texts elevate the status of the Levites and their importance in temple functions.

This is not, however, the only voice present in rabbinic sources. In what follows, I aim to show that some rabbinic descriptions concerning the location of the Levitical singing betray a different attitude towards the status of the Levites in the temple.

According to m. Tamid 7:3, it is necessary for Ben Arza to be able to see the deputy high priest standing on the altar, so that he can observe the waving of the flag and signal the beginning of the singing. Other rabbinic sources present flags (סודרין) as a signal used in cases where the distance in question is too large to allow for verbal communication. ${ }^{56}$ This does not, however, necessitate that in our case the Levites were located at a distance from the altar, since it is possible to explain the use of flags as motivated by a preference for quick and elegant signaling.

According to t. Pesah. 4:11, the Levites stand on the dukan. What was this dukan and where was it placed in the temple? The term dukan does not appear in Biblical Hebrew, and in early rabbinic sources it appears only in the context of the Levitical singing in the temple. Later rabbinic sources do use the term to refer to the place where the priests bless the people, both in the temple and in the synagogue, but Yaakov Spiegel has shown that this usage appears only in the Babylonian Talmud, and not in Palestinian sources. ${ }^{57}$ The term is usually understood to denote a platform that is higher than its surroundings. However, this interpretation is based only on the contexts in which the term appears, while the etymology of the word remains uncertain. The Aramaic

55 m. Pesah. 5:7 also points to a close connection between the act of sacrifice and the singing of the Hallel. However, it does not say who were the singers. See also Lieberman, Tosefta Ki-feshuțah, 4:561-62.

$5^{6} \quad$ m. Yoma 6:8; m. Sanh. 6:1; t. Sukkah 6:4.

57 Spiegel, "Platform." 
New Jerusalem text from Qumran features the plural form דוכניא, probably in the sense of a square located in front of a house or a gate. ${ }^{58}$ The same text also has the word דכא, meaning "a chamber."59 It is possible only to conclude that the word dukan was an architectural term, already in the Second Temple period, whose exact meaning is not clear.

The most detailed description of the dukan and its location is provided by m. 'Arak. 2:6:

There were never less than twelve Levites standing on the dukan, and their number could be increased to infinity. No minor could enter the courtyard ('azara) to take part in the service except when the Levites stood up to sing. Nor did they join in the singing with harp and lyre, but with the mouth alone, to add flavor to the music.

Rabbi Eliezer b. Yaakov said: they did not count in the required number, nor did they stand on the dukan. Rather they would stand on the ground, so that their heads were between the feet of the Levites. And they were called the youth of the Levites.

According to this mishnah, a minor is not allowed to enter the courtyard except when the Levites sing, at which point children (probably Levites) enter the courtyard to sing with the Levites. This description assumes that the dukan was located inside of the courtyard. More specific information can be gleaned from the tannaitic midrash Sifre Zuta to Numbers (szN). Among a series of homilies regarding the exclusion of impure individuals from the camp (Num 5), sZN brings a long list of the "ten sanctities" - ten graduated circles of sanctity around the temple. Each circle excludes a certain kind of impurity or class of people. A parallel list appears in m. Kelim 1:6-9, and there are some significant differences between the two lists. ${ }^{60}$ I will focus on the descriptions of the temple courts in both lists:

58 The scroll reads (5Q15 1 ii 13): ומשח ת[ח[י]מי דוכנ[יא אורכהון אמין] תשע עשרה. DiTommaso's translation reads: "then he measured the edges of the platforms, their length cubits nineteen" (DiTommaso, New Jerusalem, 49-50). DiTommaso drew his rendering from J.T. Milik, who first published the main fragments of the text and translated the term as "platform." Chyutin translates it as "courtyards," a more likely interpretation given the size of the area described (nineteen cubits). See Chyutin, New Jerusalem, 29-30. DiTommaso, New Jerusalem, 49, 56. This word also appears in Tg. 1 Kgs 14:28, where the דוכא : דוכא דרהטיא is translated as Tא הרצים See also the Tg. 2 Chr 12:11 דרהטוניא.

6o For a full survey of the differences between the two lists, see Baitner, Sifre Zuta, 29-38. 


\section{Sifre Zuta to Numbers $5: 2^{61}$}

Israelites who have passed through the period of the setting of the sun [after their purification] (מעורבי שמש) may enter the courtyard of the priests, [which is] 11 [cubits] in breadth and 135 in length, but they are not allowed to stand on the dukan.

And the Levites were able to stand on the dukan, but could not go any further.

\section{m. Kelim 1:8}

The court of the priests is holier, for Israelites may not enter it except when they are required to do so: for leaning the hands [on the sacrifice], slaughtering, or waving [the sacrifice].

While szN allows completely pure Israelites ${ }^{62}$ to enter the priestly court without any restriction, ${ }^{63}$ the mishnah stipulates that they may only enter so as to perform specific actions necessary for the offering of their personal sacrifices. The Levites, according to szN, rank higher than the Israelites, and so they may stand on the dukan but cannot proceed farther. This description indicates that the dukan was located in the inner section, i.e., the western part, of the priestly court. According to the description of the courtyard found in several early rabbinic sources, this location should be very close to the altar. ${ }^{64}$ This

61 Horovitz, Sifre Zuta, 228. My translation.

62 This is a unique use of the term מעורבי שמש in rabbinic literature. The sense of "completely pure" resembles the use of the phrase להעריבות השמש in 4QMMT. See Baitner, Sifre Zuta, 32.

63 Scholars have been bothered by this lenient approach of szN and the discrepancy between SzN and the Mishnah, and they have consequently attempted to correct the text. Since no complete manuscript of szn has survived, most of its text has been reconstructed based on medieval testimonia. For a full description of the textual evidence, see Kahana, "Halakhic Midrashim," 91-95. The reading "to the court of the priests" is based on quotations of this passage that appear in Yalkut Shimoni and Bamidbar Rabba (see Horovitz, Sifre Zuța, 228). Nevertheless, Lieberman (Sifre Zuța, 18 n. 28) has explained this version as the product of a scribal error, and suggested that the text originally read "to the court of the Israelites." I cannot accept Dubrau's preference for the variant attested by Midrash Hagadol, since this version probably reflects an attempt to adapt szN to agree with m. Kelim 1:8 and Maimonides (Hilchot Beit Habechira 7:19), who claims that the Israelites are allowed to enter the priestly courtyard only for the performance of sacrificial acts. See Dubrau, Sifre Zuta, 246-47; 280-81.

64 m. 'Arak. 2:3-4 describes the playing of flutes near the altar during festivals. It is not clear who played the flutes: R. Meir claimed that the players were the slaves of priests, R. Yose argued for high-class Israelites, and R. Hanania ben Antignas suggested Levites. The Talmud (b. 'Arak. 11a) assumes that the flute playing accompanied the Levitical singing, and therefore deliberates as to whether the "essence of the liturgy" (עיקר שירה) is the performance by human voices (which would lead to the conclusion that the players do 
location accords well with the sources that describe the singing of the Levites as closely related to the sacrifices offered on the altar. However, the dukan and the Levites are absent from $\mathrm{m}$. Kelim. Later on, I will suggest that this absence may be significant.

An architectural description of the same area in the temple appears in m. Mid. 2:6:

The Court of the Israelites was one hundred and thirty-five cubits in length by eleven in breadth. Similarly, the Court of the Priests was one hundred and thirty-five cubits in length by eleven in breadth. And a row of mosaic stones (ראשֶן פסיפסין) separated the Court of the Israelites from the Court of the Priests.

Rabbi Eliezer b. Yaakov says: there was a step, a cubit high, on which the dukan was placed, and it had three steps each of half a cubit in height. In this way the Court of the Priests was made two and a half cubits higher than that of the Israelites.

According to the first anonymous speaker in this mishnah, the court of Israel was equal in size to that of the priests, and a certain kind of mosaic floor decoration marked the boundary between the two areas. ${ }^{65}$ However, Rabbi Eliezer ben Yaakov, the second speaker in this mishnah, claims that the border between the two courts was much more pronounced, and that the priestly court was two and a half cubits higher than the court of the Israelites. The dukan, which included a staircase of three steps, served as the border between the courts. The location of the dukan according to Rabbi Eliezer ben Yaakov differs from that suggested by m. 'Arak. 2:6 and from that of szN. While the latter probably reflects the view that the dukan stood right next to the altar, at the western edge of the priestly court, Rabbi Eliezer ben Yaakov places it in the eastern part of the priestly court, near the court of Israel. Since the breadth of the priestly court is only eleven cubits, this is not a considerable distance. It does, however, reflect a meaningful difference concerning the status of the Levites in the temple's hierarchy. The architectural arrangement proposed by Rabbi Eliezer ben Yaakov models a clear hierarchy, one that is reflected both in the physical height and in the distance from the sanctuary. On the vertical plane, the priestly court is higher, the court of the Israelites is lower, and the

not have to be Levites) or the instrumental playing (which would mean that the players must be Levites). If read in light of the Talmud's assumption, this mishnah offers further evidence that the Levitical singing was performed near the altar. See also Benovitz, "Halil."

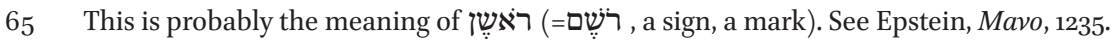


Levites sing on a dukan located in the space between the two. On the horizontal plane, the priests are the nearest to the altar and sanctuary, the Israelites are the farthest, and the Levites are in the middle. ${ }^{66}$

The dukan is never mentioned in Mishnah Middot aside from this statement of Rabbi Eliezer ben Yaakov. The Levites, however, do appear elsewhere, in m. Mid. 2:5:

Fifteen steps led up from it (from the court of women) to the court of the Israelites, corresponding to the fifteen songs of ascents in the Psalms, and upon which the Levites stand while singing. They were not rectangular but circular like the half of a threshing floor.

There were chambers underneath the court of the Israelites which opened into the court of women, where the Levites used to keep lyres and harps and cymbals and all kinds of musical instruments.

According to this mishnah, the Levites stood on the fifteen steps that led from the women's court to the court of the Israelites. The mishnah also relates the fifteen steps to the fifteen songs of ascents in Pss 120-134. A very similar notion appears in $\mathrm{m}$. Sukkah 5:4, amid a description of the water libation celebration that took place during the festival of Sukkot:

And the Levites with innumerable harps, lyres, cymbals and trumpets and other musical instruments stood upon the fifteen steps leading down from the Court of the Israelites to the Court of the Women, corresponding to the fifteen songs of ascents in the Psalms, upon which the Levites stand while singing.

Some Mishnah commentators, following Rashi in b. Sukkah $51 b,{ }^{67}$ claimed that the Levites used to sing on the stairs only during this celebration of the water libation, and that they usually sang on the dukan, near the altar. However, there is other possible evidence that the practice depicted in m. Mid. 2:5 is not unique to the water libation celebration. First, the final sentence in $\mathrm{m}$. Sukkah 5:4 (see above) is unnecessarily repetitive: "the Levites ... stood upon the fifteen steps ... upon which the Levites stand." This suggests that the final

66 Hillel Mali (Temple in Mishnah, 95-97) has convincingly analyzed several tannaitic sources, including the one in question, in which Rabbi Eliezer ben Yaakov objects to unnecessary staying in the inner parts of the sanctuary. It may be true that his description of the dukan aligns with this wider tendency, but it also situates the Levites in a middle position, as I argue.

67 This is also the interpretation offered by Maimonides, Hilchot Beit Habechira 6:6. 
sentence was copied from m. Mid. 2:5, and the description of the Levites on the steps did not originally relate to the celebration of the water libation. Second, m. Mid. 2:5 relates the architecture of the western part of the women's court to the Levitical singing. This connection is evident in the comparison between the number of steps and the ascent songs, as well as in the description of the chambers for the musical instruments that opened onto the women's court. It is a connection that makes more sense if the singing of the Levites on the stairs was not limited to one annual event.

Further evidence may be deduced from the special vocabulary that the כינורות נבלים ומצילתים וכל כלי שיר This combination of כינורות (lyres), נבלים (harps), and especially מצילתים (cymbals) is typical of the biblical descriptions of Levitical singing found in Ezra and Nehemiah, and especially in Chronicles. These books present singing as a daily duty, and so it makes sense to understand Mishnah Middot in the context of daily singing, and not only that of the water libation celebration. Explicit evidence for this reading is provided by t. 'Arak. 2:2:

Rabbi Eliezer b. Yaakov says: the youth of the Levites were the sons of the nobility of Jerusalem. They were in the women's court. Their heads were between the feet of the Levites, to add flavor to the music. As it is said: "And Jeshua with his sons, Qadmiel with his sons, and the sons of Judah, etc."68

Although Rabbi Eliezer ben Yaakov's statement in the Tosefta here resembles that which appears in m. 'Arak. 2:6, there is a crucial difference: according to the version found in the Tosefta, the Levitical singing is performed in the women's court and not on the dukan inside the courtyard, as in the Mishnah.

The biblical allusions to Ezra and Nehemiah, Chronicles, and the songs of ascent in Psalms, may create the impression that the women's court is the traditional place of the Levitical singing, and that this tradition dates from the days of David. Despite the aura of antiquity and importance that this impression lends to Levitical singing, one should not forget a small but highly significant point - according to all rabbinic views, the women's court and these fifteen steps are outside of the holiest area of the temple. Some impure persons who are forbidden to enter the Israelites court can enter the women's court (m. Kelim 1:8; t. Kelim B. Qam. 1:8), and no sacrificial worship can be performed

68 The Tosefta quotes Ezra 3:9 loosely so as to emphasize the place of the "sons" in the Levitical worship. 
in it. Placing the Levites in the women's court effectively means placing them outside of the temple.

\section{$5 \quad$ Conclusion}

We have analyzed three different opinions in early rabbinic sources concerning the location of the Levitical singing: (1) on the dukan next to the altar, (2) on the dukan between the courts of the priests and the Israelites, and (3) on the staircase in the women's court. Traditional commentators glossed over this diversity, taking the second location as the default position of the Levites and interpreting all references to the dukan accordingly. They effectively eliminated the third opinion by claiming that the singing in the women's court occurred only at the celebration of the water libation, while the daily singing was performed on the dukan. Büchler has tried to minimize the diversity in a different manner, claiming that the dukan was the place where the officer of the singing (Ben Arza) - and he alone - stood. From his position on the dukan, Ben Arza was able to see the flag of the deputy and to signal to the Levites, who stood outside of the Nicanor gate, that is, in the women's court. ${ }^{69}$ Büchler did not discuss the different location of the dukan presented in SzN, and he also made no mention of t. 'Arak. 2:2, which uses nearly the same words as m. 'Arak. 2:6, but places the Levites in the women's court.

Identification of these three different descriptions opens up questions as to what motivates their formulation, and whether and how they reflect a historical reality. Since non-rabbinic sources do not discuss the exact location of the temple singing, we must evaluate the rabbinic references to such a location based on internal evidence. It seems to me that the sources that mention the dukan represent a Second Temple tradition. This term, as we saw above, was an architectural term in usage in Second Temple period Aramaic, and it is attested in Rabbinic Hebrew only in temple contexts, which suggests that rabbinic sources preserve a Second Temple tradition linking the dukan to the liturgical singing. Almost all descriptions view the dukan as located inside the 'azara. Other sources that place the Levites inside the 'azara, although they do not mention the dukan, appear to reflect a similar view. To my mind, the other two descriptions do not reflect an ancient tradition, but a later rabbinic tendency to portray the Levites as distant from the inner parts of the temple. R. Eliezer ben Yaakov describes the dukan as located farther to the east, although still in the border between the courtyards. Thus, on the one hand he

69 Büchler, Priester, $125^{-27}$. 
views it as inside the 'azara, in accordance with the description in m. 'Arak. 2:6, but on the other hand he distances the Levites from the priestly court. The anonymous voice that appears in Mishnah Middot is even more radical. It does not mention the dukan at all, and it places the Levites even farther away from the inner temple, locating them in the staircase of the women's court and therefore outside of the holy temple courtyard. Furthermore, the description of the Levites on the steps in m. Mid. 2:5 appears just before R. Eliezer ben Yaakov's description of the dukan in m. Mid. 2:6. This sequence, along with the fact that R. Eliezer b. Yaakov does not mention the Levites explicitly, suggests an attempt to blur the function of the dukan. Indeed, R. Shemaiah of Soissons (France, eleventh century) presents in his commentary to Mishnah Middot the dukan as the platform of the priests, rather than that of the Levites. Against the general scholarly view that this detail in Mishnah Middot reflects a tradition from the Second Temple period, I argue that the Mishnah instead presents a reworked description, drawing on scriptures in a learned fashion to establish it as an older tradition. ${ }^{70}$

While the contradictions between the sources appear as a minute disagreement about the location of the singing, they suggest a larger debate about the status of the Levites in the temple. The notion that the dukan stood next to the altar reflects the view that the Levitical singing constitutes an important part of the sacrificial worship. By placing the dukan between the court of the priests and that of the Israelites and claiming that a physical separation divided the two courts, Rabbi Eliezer ben Yaakov stresses the hierarchy between the different groups and portrays the Levites as occupying a middle position within that hierarchy. The third opinion, which views the Levites as located in the women's court, in effect excludes them from any official duty in the temple service proper. This third approach resembles the main rabbinic attitude towards the location where the Levites stood guard, an approach that, in contrast to Philo's view, excludes the Levites from standing guard inside of the courtyard.

70 For a similar description of Mishnah Middot, see Rosen-Zvi, Sotah, 164 n. 6o. Both the view of the anonymous voice of Middot and that of R. Eliezer ben Yaakov effectively reshape the architecture of the temple. R. Eliezer claims an otherwise unknown architectural feature that divides the court of the priests from that of the Israelites, contrary to the description of "a row of mosaic stones," made by the anonymous voice in the same mishnah. Similarly, the anonymous voice of Middot describes the fifteen steps and the chambers for the musical instruments as elements designed for the Levitical singing. I suggest that these examples bear important methodological implications for interpreting rabbinic descriptions of temple architecture. Rather than taking these descriptions as straightforward historical information, as is sometimes done, it can be productive to consider the ideological claims that might underlie and motivate them. Dr. Yael Fisch and I will offer more examples in a forthcoming article. 
This implicit rabbinic debate about the status of the Levites may resemble similar debates attested in Josephus' story about the Levites in the times of Agrippa II, and perhaps in the obscure passage in 4 QInstruction. Both sources point to an attempt to elevate the Levitical status in the temple, as well as strong resistance to this attempt. The similarities, however, are limited. The rabbinic sources, despite their internal differences, shared two basic assumptions: (1) that the Levites are a distinct social group, and (2) that the temple singing is exclusively performed by the Levites. With the sole exception of Plutarch ${ }^{71}$ no non-rabbinic source reflects both of these assumptions together. Thus, Josephus describes the elevation of the Levites as an innovative move, while in rabbinic sources, according to my reading, the relatively late views have tried to downplay the role of the Levites in the temple. The rabbinic portrayal of the Levites may reflect the influence of debates in the Second Temple period and resistance to heightened Levitical status, yet the status that the rabbinic texts unquestioningly ascribe to the Levites assumes what one might call a "Levitical renaissance." It is hard to discern the reasons for this "renaissance." It may be related to the influence of certain biblical descriptions, such as that of Chronicles, which impacted the retrospective description of the temple and its worship by the rabbis. Alternatively, it might be an expression of a larger trend of reinforcement of the Levitical identity in the post-70 CE Jewish society, a trend that might also be attested, as mentioned earlier, in the epigraphical material from late antique Palestinian synagogues. A contemporary social situation in which Levites were recognized as a distinct group with some religious privileges may have been projected backwards by the rabbis to the time of the temple.

The history and fate of the Levites are indeed obscure, particularly during the late Second Temple period. The rabbinic literature is another link in this long and obscure chain. Werman has convincingly argued that certain individuals were identified as Levites in the late Second Temple period. Some of them were indeed singers or served as other temple functionaries, but it is unlikely that there were temple duties performed exclusively by Levites. There were also attempts, inspired by biblical precedents, to elevate the Levitical status in the temple during the first century and probably earlier. These attempts produced strong resistance. In this article I have shown that this debate underlies a rabbinic dispute about the location of the Levitical singing in the temple. Yet even though they question the location and hence the exact status of the Levites, the rabbis assume that the Levites were a distinct group with exclusive

See above n. 37 . 
temple duties. This assumption may reflect a shift in the status of the Levites after the destruction of the temple.

\section{Bibliography}

Altman, Peter. "What Do the 'Levites in Your Gates' Have to Do with the 'Levitical Priests'? An Attempt at European-North American Dialogue on the Levites in the Deuteronomic Law Corpus." In Levites and Priests in Biblical History and Tradition, ed. Mark Leuchter and Jeremy Michael Hutton (Atlanta: Society of Biblical Literature, 2011), 135-54.

Baitner, Hallel. Studies in the Mishna of Sifre Zuta and Its Integration into the Midrash, Dissertation (Department of Talmud, Hebrew University of Jerusalem, 2017) [Hebrew].

Beckwith, Roger T. "The Courses of the Levites and the Eccentric Psalms Scrolls from Qumran." Revue de Qumrân 11 (1984), 499-524.

Begg, Christopher T. "The Levites in Josephus." Hebrew Union College Annual 75 (2004), $1-22$.

Benovitz, Moshe. "The Halil that Played before the Altar." In Ke-Tavor Be-harim: Mehqarim Ba-Torah Shebe-'al Peh Mugashim Li-Profesor Yosef Tabori, ed. Arnon Atzmon and Zur Shafir (Alon Shevut: Tevunot, 2013), 21-41 [Hebrew].

Brooke, George J. "Levi and the Levites in the Dead Sea Scrolls and the New Testament." In Mogilany 1989:Papers on the Dead Sea Scrolls Offered in Memory ofJean Carmignac, ed. Zdzisław J. Kapera (Krakow: Enigma, 1991), 105-27.

Büchler, Adolf. Die Priester und der Cultus im letzten Jahrzehnt des jerusalemischen Tempels (Wien: Hölder, 1895).

Chyutin, Michael. The New Jerusalem Scroll from Qumran: A Comprehensive Reconstruction (Sheffield: Sheffield Academic Press, 1997).

DiTommaso, Lorenzo. The Dead Sea New Jerusalem Text: Contents and Contexts (Tübingen: Mohr Siebeck, 2005).

Dubrau, Alexander A. Der Midrasch Sifre Zuta: Textgeschichte und Exegese eines spätantiken Kommentars zum Buch Numeri (Berlin: LIT, 2017).

Dueck, Daniela. "The Feast of Tabernacles and the Cult of Dionysus: A Cross-Cultural Dialogue." Zion 73 (2008), 119-38 [Hebrew].

Emerton, J.A. "Priests and Levites in Deuteronomy: An Examination of Dr. G. E. Wright's Theory." Vetus Testamentum 12 (1962), 129-38.

Epstein, Jacob N. Mavo Le-nusah Ha-Mishnah (Jerusalem, 1948).

Feldman, Louis H. Josephus's Interpretation of the Bible (Berkeley: University of California Press, 1998). 
Finkelstein, Louis. Sifre 'al Sefer Devarim: 'im Hilufe Girsa'ot ve-He'arot (New York, Jewish Theological Seminary of America, 1969).

Fraade, Steven D. "Shifting from Priestly to Non-Priestly Legal Authority: A Comparison of the Damascus Document and the Midrash Sifra." Dead Sea Discoveries 6 (1999), 109-25.

Gillingham, Susan. "The Levitical Singers and the Compilation of the Psalter." In Trägerkreise in den Psalmen, ed. Frank-Lothar Hossfeld, Johannes Bremer, and Till Magnus Steiner (Bonn: Bonn University Press, 2016), 35-59.

Haran, Menahem. Temples and Temple-Service in Ancient Israel: An Inquiry into the Character of Cult Phenomena and the Historical Setting of the Priestly School (Oxford: Clarendon, 1978).

Harlé, Paul, and Didier Pralon. La Bible d'Alexandrie, vol. 3 Le Lévitique (Paris: Cerf, 1988).

Hidary, Richard. "Revisiting the Sabbath Laws in 4Q264a and Their Contribution to Early Halakha." Dead Sea Discoveries 22 (2015), 68-92.

Horovitz, Hayim S. Sifre de-be Rav: 'im Hilufe Girsa'ot ve-He'arot; Mahberet 1. Sifre 'al Sefer ba-Midbarve-Sifre Zuta (Leipzig: Fock, 1917).

Hurvitz, Avi. “The Term 'Lishkhot Sharim' (Ezek 40:44) and Its Place in the Cultic Terminology of the Temple." Scripta Hierosolymitana 31 (1986), 49-62.

Hurvitz, Avi. A Concise Lexicon of Late Biblical Hebrew: Linguistic Innovations in the Writings of the Second Temple Period (Leiden: Brill, 2014).

Ilan, Tal. Lexicon of Jewish Names in Late Antiquity, 4 vols. (Tübingen: Mohr Siebeck, 2002-12).

Janzen, David. Chronicles and the Politics of Davidic Restoration: A Quiet Revolution (London: Bloomsbury, 2017).

Japhet, Sara. Ideology of the Book of Chronicles and Its Place in Biblical Thought (Winona Lake: Pennsylvania State University Press, 2009).

Kahana, Menahem. "The Halakhic Midrashim." In The Literature of the Sages, vol. 2, ed. Shmuel Safrai, Zeev Safrai, Joshua Schwartzm and Peter J. Tomson (Assen: Van Gorcum, 2006), 3-105.

Kahana, Menahem. Sifre Ba-midbar: Mahadurah Mevo'eret, 4 vols. (Jerusalem: Magnes, 2011-2015).

Knoppers, Gary N. "Hierodules, Priests, or Janitors? The Levites in Chronicles and the History of the Israelite Priesthood." Journal of Biblical Literature 118 (1999), 49-72.

Kugel, James. "Levi's Elevation to the Priesthood in Second Temple Writings." The Harvard Theological Review 86 (1993), 1-64.

Kugler, Robert A. From Patriarch to Priest: The Levi-Priestly Tradition from Aramaic Levi to Testament of Levi (Atlanta: Scholars Press, 1996).

Kugler, Robert A. "The Priests of Qumran: The Evidence of References to Levi and Levites." In The Provo International Conference on the Dead Sea Scrolls: Technological 
Innovations, New Texts, and Reformulated Issues, ed. Donald Parry and Eugene Ulrich (Leiden: Brill, 1999), 465-79.

Kugler, Robert A. "Levi, Levites." In The New Interpreter's Dictionary of the Bible, 5 vols., ed. Katharine Doob Sakenfeld (Nashville: Abingdon, 2006), 3:642-643.

Kugler, Robert A. "Priests and Levites." In The New Interpreter's Dictionary of the Bible, 5 vols., ed. Katharine Doob Sakenfeld (Nashville: Abingdon, 20o6), 4:596-613.

Levine, Baruch A. "Leviticus, Book of." In The Anchor Bible Dictionary, 6 vols. (New York: Doubleday, 1992), 4:312.

Levine, Baruch A. Numbers: A New Translation with Introduction and Commentary (New York: Doubleday, 1993-200o).

Lieberman, Saul. Sifre Zuța (Midrashah Shel Lod) Talmudah Shel Qisarin (New York: Bet Ha-Midrash Le-Rabanim Shebe-Ameriqah, 1968).

Lieberman, Saul. Tosefta Ki-feshuțah: Be'ur Arokh La-Tosefta, 10 vols. (New York: Mekhon Me'ir Leyb Rabinovits, 1955-88).

MacDonald, Nathan. Priestly Rule: Polemic and Biblical Interpretation in Ezekiel 44 (Berlin: De Gruyter, 2015).

Mali, Hillel. Descriptions of the Temple in the Mishnah: History, Redaction and Meaning, Dissertation (Bar-Ilan University, 2018) [Hebrew].

Meyer, Rudolf. "Levitische Emanzipationsbestrebungen in nachexilischer Zeit." Orientalistische Literaturzeitung 41 (1938), 721-28.

Milgrom, Jacob. “Studies in the Temple Scroll." Journal of Biblical Literature 97 (1978), 501-23

Min, Kyung-Jin. The Levitical Authorship of Ezra-Nehemiah (London: T\&T Clark, 2004).

Mizrahi, Noam. "Priests of Qoreb: Linguistic Enigma and Social Code in the Songs of the Sabbath Sacrifice." In Hebrew of the Late Second Temple Period, ed. Eibert Tigchelaar and Pierre Van Hecke (Leiden: Brill, 2015), 37-64.

Naveh, Joseph. 'Al Pesefas va-Even: Ha-ketovot Ha-Aramiyot veha-Tvriyot Mi-bateha-keneset Ha-'atiqim (Jerusalem: Ha-ḥevrah La-ḥaqirat Erets-Yiśra'el ve-'atiqoteha, 1978).

Neusner, Jacob. The Tosefta (Peabody: Hendrickson, 2002)

Noam, Vered, and Elisha Qimron. "A Qumran Composition of Sabbath Laws and Its Contribution to the Study of Early Halakah." Dead Sea Discoveries 16 (2009), 55-96.

O’Brien, Julia M. Priest and Levite in Malachi (Atlanta: Scholars Press, 1990).

Qimron, Elisha. Ha-hiburim Ha-'Tvriyim, Mahadurah Meshulevet, 3 vols. (Tel-Aviv: n.p., 2020). https://zenodo.org/record/373795o\#.XoXRs6gzaiM

Rosenthal, Eliezer S. "The Giv'at ha-Mivtar Inscription." In P'raqim: Yearbook of the Schocken Institute for Jewish Research of the Jewish Theological Seminary of America, vol. 2, ed. Eliezer S. Rosenthal (Jerusalem: Schocken Institute, 1969-74), 335-73 [Hebrew]. 
Rosen-Zvi, Ishay. Ha-Teqes She-lo Hayah: Miqdash, Midrash U-migdar Be-Masekhet Soțah (Jerusalem: Magnes, 2008).

Sarna, Nahum M. "Psalms, Book of." In Encyclopedia Judaica, 16 vols. (Jerusalem: Keter, 1971), 13:1315-17.

Schwartz, Baruch J. “Review of Priest and Levite in Malachi, by Julia M. O'Brien.” AJS Review 18 (1993), 288-91.

Scott, James M. "Korah and Qumran." In The Bible at Qumran: Text, Shape, and Interpretation, ed. Peter W. Flint, Studies in the Dead Sea Scrolls and Related Literature (Grand Rapids: Eerdmans, 2001), 182-202.

Spiegel, Yaakov S. "Who Stood on the Platform and Who Went up to It?" Sidra: A Journal for the Study of Rabbinic Literature 14 (1998), 63-137 [Hebrew].

Stackert, Jeffrey. "The Cultic Status of the Levites in the Temple Scroll: Between History and Hermeneutics." In Levites and Priests in Biblical History and Tradition, ed. Mark Leuchter and Jeremy M. Hutton (Leiden: Brill, 2012), 199-214.

Stern, Menahem. "Aspects of Jewish Society: The Priesthood and other Classes." In The Jewish People in the First Century: Historical Geography, Political History, Social, Cultural and Religious Life and Institutions, vol. 2, ed. Shmuel Safrai, Menahem Stern, David Flusser, and Willem C. van Unnik (Assen: Van Gorcum, 1976), 561-63o.

Stern, Menahem. Greek and Latin Authors on Jews and Judaism, 3 vols. (Jerusalem: Israel Academy of Sciences and Humanities, 1974-84).

Strugnell, John, Daniel J. Harrington, and Torleif Elgvin. Qumran Cave 4. XXIV, Sapiential Texts. Part 2: 4 QInstruction (Mûsār Lĕ Mēvîn): 4 Q415ff.: With a Re-edition of 1Q26, DJD 34 (Oxford: Clarendon, 1999).

Tigchelaar, Eibert J. C. To Increase Learning for the Understanding Ones: Reading and Reconstructing the Fragmentary Early Jewish Sapiential Text 4QInstruction (Leiden: Brill, 2001).

Wacholder, Ben Zion. "David's Eschatological Psalter 11Q Psalms." Hebrew Union College Annual 59 (1988), 23-72.

Werman, Cana. "Levi and Levites in the Second Temple Period." Dead Sea Discoveries 4 (1997), 211-25. 